\title{
Distribution of total phenols, flavonoids and hypericin in different plant organs of wild-growing St. John's-wort (Hypericum perforatum L., Hypericaceae) from North Macedonia
}

\author{
Arijeta Shabani $^{1 *}$, Marija Karapandzova ${ }^{1}$, Ivana Cvetkovikj Karanfilova ${ }^{2}$, \\ Gjoshe Stefkov ${ }^{1}$, Maja Simonoska Crcarevska ${ }^{3}$, Svetlana Kulevanova ${ }^{1}$ \\ ${ }^{I}$ Institute of Pharmacognosy, Faculty of Pharmacy, \\ Ss. Cyril and Methodius University,Majka Tereza 47, 1000 Skopje, R. North Macedonia \\ ${ }^{2}$ Center for natural product research, Faculty of Pharmacy, \\ Ss. Cyril and Methodius University, Majka Tereza 47, 1000 Skopje, R. North Macedonia \\ ${ }^{3}$ Institute of Pharmaceutical technology, Faculty of Pharmacy, \\ Ss. Cyril and Methodius University, Majka Tereza 47, 1000 Skopje, R. North Macedonia
}

Received: September 2019; Accepted: October 2019

\begin{abstract}
Hypericum perforatum L. (Hypericaceae) contains secondary metabolites that show noteworthy pharmacological activities. Therefore, the content of total phenols, flavonoids and hypericin from whole herb, flowers and leafs from St. John's-wort collected over four consecutive seasons (2014-2017) from three different locations in western part of North Macedonia (Tetovo, Debar and Mavrovo) were investigated by three different spectrophotometric methods (using Folin-Ciocalteu reagent, $\mathrm{NaNO}_{2}-\mathrm{AlCl}_{3}-\mathrm{NaOH}$ and mixture of water/tetrahydrofuran). The quantity of total phenols obtained from different plant organs (leafs, whole herb and flowers) were 35.1583.08 mg GAE/g, 55.41-98.52 mg GAE/g and 75.44-121.19 mg GAE/g, respectively. Afterword the total flavonoids contents were: 61.64-106.86 mg CE/g, 73.04-117.57 mg CE/g and 108.65-125.35 mg CE/g in leafs, whole herb and flowers, respectively, while the hypericin amounts were: $0.03-0.17 \mathrm{mg} / \mathrm{g}, 0.04-0.29 \mathrm{mg} / \mathrm{g}$ and $0.07-0.60 \mathrm{mg} / \mathrm{g}$ in leafs, whole herb, and flowers, respectively. Significant differences were observed in the quantities of total phenols, flavonoids and hypericin between the locations of harvesting, while the collection seasons were found not to be significant. Additionally, it can be seen that the flowers are characterized by higher amounts of total phenols, total flavonoids and hypericin compared to total herb and leaf in all three locations, therefore harvesting of St. John's-wort should be made in a manner of obtaining larger quantities of flowers as harvesting material which could increase the bioactive compounds in the herbal row material.
\end{abstract}

Keywords: Hypericum perforatum, plant organs, total phenols, flavonoids, hypericin, statistical analysis

\section{Introduction}

Hypericum perforatum L. (St. John's-wort) is an important natural source of secondary metabolites with a wide range of pharmacological attributes including antiviral, antimicrobial, anti-inflammatory, antioxidant, hepatoprotective and anti-tumoral activity (Crocket and Robson, 2011; Linde et al., 1996; Muller, 2005; Saddiqe et al., 2010). Today, this plant is best known for its use in

\footnotetext{
*arijetashabani@yahoo.com
} 
the treatment of mild to moderately severe depressive disorders (Linde and Mulrow, 2003).

The major active constituents are considered to be naphtodianthrones (pseudohypericin, hypericin), phloroglucinol derivates (mainly hyperforin and adhyperforin), flavonoids, catechin tannins, procyanidines and smaller amounts of essential oil (Bradley, 2006; Nahrstedt and Butterweck, 1997). The antidepressant activity of St John's Wort extracts has been variously attributed to the hypericin and pseudohypericin (Butterweck et al., 2002), hyperforin (Chatterje et al., 1998; Muller et al., 2001; Singer et al., 1999; Wonnemann et al., 2001) and to several flavonoids (Butterweck et al., 2000; Calapai et al., 1999).

From a pharmacological point of view, the hypericins are the most interesting compounds of $H$. perforatum. Massive inhibition of monoamine oxidase A (MAO-A) can be shown with the total extract of $H$. perforatum (Thiede and Walper, 1994). Using pure hypericin, no relevant inhibiting effects can be shown because $H$. perforatum extracts have only weak activity in assays related to the mechanisms of the synthetic antidepressants, that is, inhibition of MAO, catechol Omethyltransferase, or serotonin reuptake. It has been postulated that the clinical efficacy of $H$. perforatum extract could be attributed to the combined contribution of several mechanisms, each one too weak by itself to account for the overall effect (Bennet et al., 1998). Hypericin has shown antiviral activity against several types of viruses, including herpes simplex virus types 1 and 2 (Weber et al., 1994; Wood et al., 1990) and human immunodeficiency virus (HIV) (Hudson et al., 1991; Lavie et al., 1989; Meruelo et al., 1988) and has been tested as a photosensitizer in the treatment of cancer (Hamilton et al., 1996; Liu et al., 2000; Kamuhabwa et al., 2000).

The flavonoid glycosides (rutin, hyperosid, isoquercitrine, quercitrine) and aglycones (quercetin, kaempferol and luteolin) found in Hypericum are also considered to be potentially therapeutic compounds due to their anti-inflammatory, antioxidative, antimicrobial and spasmolytic effects (Luo et al., 2004; Morales and Lozoya, 1994; Zou et al., 2004). Besides, total phenolic compounds are usually attributed to antioxidant activity of plant row materials (Kahkonen et al., 1999) as well as of Hypericum species (Zou et al., 2004).

However, many authors found great variations in the content of total phenols, flavonoids and hypericins in $H$. perforatum and other species of Hypericum (Cirak et al., 2006; Toker, 2009) that might influence on the biological activity of the plant extracts. On the other side, very little is known about the distribution of total phenols, flavonoids and hypericins in different parts of the $H$. perforatum which could be important in process of collection of plant material from nature. Therefore, the aim of this study was to determine the total phenols, flavonoids and hypericins in different plant organs including herb (dry over-ground part), leaves and flowers of $H$. perforatum collected in western part of North Macedonia, in order to identified seasonal variations and differences in the distribution of the secondary metabolites within the plant.

\section{Material and methods}

\section{Plant material}

Plant material was collected from three different locations in western part of North Macedonia: Tetovo, Mavrovo and Debar (Table 1) in the period 2014-2017, in full blossom of the plant (June-August). Plant identity was verified and voucher specimens were deposited at the Institute of Pharmacognosy, Faculty of Pharmacy, Skopje.

The plant material (aerial parts $25 \mathrm{~cm}$ from the top $=$ herb) was air dried, packed in paper bags and kept in a dark and cool place until analysis. For purpose of analysis, flowers (Fl) and leaves (Fol) of some samples were separated (Table 1). Before analysis plant material was milled and homogenized.

\section{Determination of total phenols}

Total phenolic content was determined with the Folin-Ciocalteu reagent according to the procedure described by Singleton et al. (1965) with slight modifications made from Karapandzova et al. (2015). Briefly, to $1 \mathrm{~mL}$ of test sample (methanol extract), $0.5 \mathrm{~mL}$ Folin-Ciocalteau reagent $(1: 10 \mathrm{v} / \mathrm{v}$ diluted with distilled water) was added and stirred for $5 \mathrm{~min}$ at room temperature. After $5 \mathrm{~min}, 0.4 \mathrm{~mL}$ of $7.5 \%$ sodium carbonate was added and made up to $10 \mathrm{~mL}$ with distilled water. These mixtures were incubated at room temperature in the dark for 2 hours. After incubation, absorbance was measured at $765 \mathrm{~nm}$ using a UV-VIS spectrophotometer. The total phenolic content was determined as $\mathrm{mg}$ of gallic acid equivalents per gram of plant material (mg GAE/g DW) using an equation obtained from standard Gallic acid calibration graph.

\section{Determination of total flavonoids}

The total flavonoid content was determined using the aluminum chloride assay described by Talari et al. (2012) with slight modification. To an aliquot of the test sample (1 $\mathrm{mL}$ methanol extracts), $4 \mathrm{~mL}$ of distilled water and 0.3 $\mathrm{mL}$ of $5 \%$ sodium nitrite were added and allowed to stand for $5 \mathrm{~min}$. Later, $0.3 \mathrm{~mL}$ of $10 \%$ aluminum chloride was added and the mixture was incubated for $6 \mathrm{~min}$. $2 \mathrm{~mL}$ of $1 \mathrm{M}$ sodium hydroxide was added and the volume was made up to $10 \mathrm{~mL}$ with distilled water. After incubation of $15 \mathrm{~min}$, the mixture turned to pink and the absorbance was measured at $510 \mathrm{~nm}$ using a UV-VIS spectrophotometer. The total flavonoids were expressed in $\mathrm{mg}$ of catechin equivalents per gram of plant material (mg CE/g DW) using an equation obtained from standard $(+)$-catechin calibration graph. 
Table 1. Plant samples of $H$. perforatum

\begin{tabular}{|c|c|c|c|c|}
\hline No. & Sample & Part of the plant & Locality & Year \\
\hline 1 & HP/14 FoL-T & leaf, dry & Tetovo & 2014 \\
\hline 2 & HP/14 FL-T & flower, dry & Tetovo & 2014 \\
\hline 3 & HP/14 HB-T & herb, dry & Tetovo & 2014 \\
\hline 4 & HP/14 FoL-D & leaf, dry & Debar & 2014 \\
\hline 5 & HP/14 FL-D & flower, dry & Debar & 2014 \\
\hline 6 & HP/14 HB-D & herb, dry & Debar & 2014 \\
\hline 7 & HP/14 FoL-M & leaf, dry & Mavrovo & 2014 \\
\hline 8 & HP/14 FL-M & flower, dry & Mavrovo & 2014 \\
\hline 9 & HP/14 HB-M & herb, dry & Mavrovo & 2014 \\
\hline 10 & HP/15 FoL-T & leaf, dry & Tetovo & 2015 \\
\hline 11 & HP/15 FL-T & flower, dry & Tetovo & 2015 \\
\hline 12 & HP/15 HB-T & herb, dry & Tetovo & 2015 \\
\hline 13 & HP/15 FoL-D & leaf, dry & Debar & 2015 \\
\hline 14 & HP/15 FL-D & flower, dry & Debar & 2015 \\
\hline 15 & HP/15 HB-D & herb, dry & Debar & 2015 \\
\hline 16 & HP/15 FoL-M & leaf, dry & Mavrovo & 2015 \\
\hline 17 & HP/15 FL-M & flower, dry & Mavrovo & 2015 \\
\hline 18 & HP/15 HB-M & herb, dry & Mavrovo & 2015 \\
\hline 19 & HP/16 FoL-T & leaf, dry & Tetovo & 2016 \\
\hline 20 & HP/16 FL-T & flower, dry & Tetovo & 2016 \\
\hline 21 & HP/16 HB-T & herb, dry & Tetovo & 2016 \\
\hline 22 & HP/16 FoL-D & leaf, dry & Debar & 2016 \\
\hline 23 & HP/16 FL-D & flower, dry & Debar & 2016 \\
\hline 24 & HP/16 HB-D & herb, dry & Debar & 2016 \\
\hline 25 & HP/16 FoL-M & leaf, dry & Mavrovo & 2016 \\
\hline 26 & HP/16 FL-M & flower, dry & Mavrovo & 2016 \\
\hline 27 & HP/16 HB-M & herb, dry & Mavrovo & 2016 \\
\hline 28 & HP/17 FoL-T & leaf, dry & Tetovo & 2017 \\
\hline 29 & HP/17 FL-T & flower, dry & Tetovo & 2017 \\
\hline 30 & $\mathrm{HP} / 17 \mathrm{Hb}-\mathrm{T}$ & herb, dry & Tetovo & 2017 \\
\hline 31 & $\mathrm{HP} / 17 \mathrm{FoL}-\mathrm{M}$ & leaf, dry & Mavrovo & 2017 \\
\hline 32 & HP/17 FL -M & flower, dry & Mavrovo & 2017 \\
\hline 33 & $\mathrm{HP} / 17 \mathrm{Hb}-\mathrm{M}$ & herb, dry & Mavrovo & 2017 \\
\hline 34 & HP/17 FoL -D & leaf, dry & Debar & 2017 \\
\hline 35 & HP/17 FL-D & flower, dry & Debar & 2017 \\
\hline 36 & $\mathrm{HP} / 17 \mathrm{Hb}-\mathrm{D}$ & herb, dry & Debar & 2017 \\
\hline
\end{tabular}

\section{Determination of total hypericin}

The total hypericin was determined by official method described in St. John's Wort monograph (Ph. Eur. 9.0, 2017). Sample solution was prepared by introducing $0.8 \mathrm{~g}$ of pulverized drug into a $100 \mathrm{~mL}$ round-bottomed flask and $60 \mathrm{~mL}$ of a mixture of 20 volumes of water and 80 volumes of tetrahydrophurane. The mixture was put on a magnetic stirrer and then boiled to fall out in a bainmarie at $70^{\circ} \mathrm{C}$ and centrifugated $(2$ minutes at $700 \mathrm{~g})$. The supernatant was decanted into a $250 \mathrm{~mL}$ flask. The residue was then taken with 60 mLof a mixture of 20 volumes of water and 80 volumes of tetrahydrophurane. The last was repeated once more and the combined extracts were evaporated to dryness. The residue was taken with $15 \mathrm{~mL}$ of methanol using ultrasound bath and transfer to a $25 \mathrm{~mL}$ volumetric flask. The $250 \mathrm{~mL}$ flask was washed with methanol and diluted with $25 \mathrm{~mL}$ with the same solvent. Afterwards the solution was centrifugated (2 minutes at $700 \mathrm{~g}$ ) and $10 \mathrm{~mL}$ of the centifugated sample was filtered through a syringe filter (0.2 $\mu \mathrm{m}$, Agilent Captiva Premium Syringe Filters). Finally, $5.0 \mathrm{~mL}$ of the filtrate was dilute with 25 mLmethanol. The absorbance of the sample solution was measured at $590 \mathrm{~nm}$ against the blank (methanol) and the percentage of total hypericins, expressed as hypericin, were calculated with the following expression: A x 125/m x 870 , where: $870=$ specific absorbance of hypericin, $\mathrm{A}=$ absorbance at $590 \mathrm{~nm}, \mathrm{~m}=$ weight of drug in grams (Longo and Schulz, 2002).

\section{Instruments}

The measurements of absorbance for determination of total phenols, flavonoids and hypericin were made on UV-VIS spectrophotometer instrument Agilent 8453, Agilent Technologies, USA. 
Table 2. The content of total phenols in herb, flower and leaf of Hypericum perforatum (mg GAE/g DW)

\begin{tabular}{|c|c|c|c|c|c|c|c|c|c|}
\hline \multirow[t]{2}{*}{ Year } & \multicolumn{3}{|c|}{ Tetovo } & \multicolumn{3}{|c|}{ Debar } & \multicolumn{3}{|c|}{ Mavrovo } \\
\hline & herb & flower & leaf & herb & flower & leaf & herb & flower & leaf \\
\hline 2017 & $77.82 \pm 0.27$ & $79.66 \pm 0.35$ & $68.67 \pm 0.89$ & $82.75 \pm 0.52$ & $85.83 \pm 0.58$ & $64.90 \pm 0.59$ & $60.16 \pm 0.19$ & $75.44 \pm 0.11$ & $42.68 \pm 0.66$ \\
\hline 2016 & $63.79 \pm 0.26$ & $113.49 \pm 0.51$ & $60.92 \pm 0.90$ & $98.52 \pm 0.58$ & $121.19 \pm 0.78$ & $83.08 \pm 0.45$ & $55.41 \pm 0.93$ & $80.67 \pm 1.00$ & $36.54 \pm 0.76$ \\
\hline 2015 & $72.72 \pm 0.81$ & $91.34 \pm 0.14$ & $56.91 \pm 0.22$ & $81.63 \pm 0.23$ & $91.05 \pm 0.76$ & $68.26 \pm 0.71$ & $62.56 \pm .061$ & $94.19 \pm 0.46$ & $47.16 \pm 0.22$ \\
\hline 2014 & $66.2 \pm 0.30$ & $109.09 \pm 0.43$ & $60.34 \pm 0.47$ & $80.12 \pm 0.14$ & $80.20 \pm 0.30$ & $59.52 \pm 0.57$ & $75.88 \pm 0.79$ & $83.65 \pm 0.86$ & $35.15 \pm 0.21$ \\
\hline
\end{tabular}

$(\mathrm{n}=3), \mathrm{DW}-$ dry weight

\section{Statistical analysis}

Data obtained from determination of total phenols, flavonoids and hypericin in different plant material (total herb, leaf and flower) are expressed as mean values \pm SD ( $n$ $=3$ ). Statistical analysis were carried out by employing two factor ANOVA without replication $(p<0.05)$ in order to determine if location and season of harvesting have statistically significant influence on each component investigated. Also, multiple comparison procedure was carried out to determine which means are significantly different from which others using Fisher's least significant difference $(L S D)$ procedure $(p<0.05)$. Statistical package STATGRAPHIC Centurion XVI version 16.1 was used for data analysis.

\section{Results and discussion}

\section{Total phenols}

Total phenols were determined in three different plant organs (whole herb, flowers and leafs) of St. John'swort (Table 2). The content of total phenols ranged from 35.15-83.08 mg GAE /g DW, 55.41- $98.52 \mathrm{mg}$ GAE/g DW and 75.44-121.19 mg GAE/g DW in leaf, herb and flower, respectively.

The highest amount of total phenols (121.19 \pm 0.78 mg GAE/g DW) were determined in flowers, particularly in one sample (HP/16 FL-D) collected in Debar in 2016 compared to all other investigated plant material, followed by one sample harvested in Tetovo from 2016 (HP/16 FL$\mathrm{T}, 113.49 \pm 0.51 \mathrm{mg} \mathrm{GAE} / \mathrm{g} \mathrm{DW})$ and then one collected in Mavrovo from 2015 (HP/15 FL-M, 94.19 $\pm 0.46 \mathrm{mg} \mathrm{GAE} / \mathrm{g}$ $\mathrm{DW})$. On the other hand, the lowest amount of total phenols was obtained in leaf as examined plant organ of Hypericum, in sample HP/14 FoL-M (35.15 $\pm 0.21 \mathrm{mg}$ GAE/g DW) harvested in Mavrovo from 2014. Leaf samples from Tetovo and Debar were characterized by low amount of total phenols in each harvest year.

\section{Total flavonoids}

Total flavonoids were determined in whole herb, in separated leaves and flowers (Table 3). The content of total flavonoids ranged from 61.64-106.86 mg CE/g DW, 73.04-117.57 mg CE/g DW and 108.65-125.35 mg CE/g DW in leaf, herb, and flower, respectively.

The highest amount of total flavonoids (125.35 \pm 0.52 $\mathrm{mg} \mathrm{CE} / \mathrm{g} \mathrm{DW}$ ) was determined in the sample, HP/16 FL-D collected in Debar in 2016 which also show highest level of total phenols, followed by two samples from Mavrovo: HP/14 FL-M (119.50 $\pm 0.67 \mathrm{mg} \mathrm{CE} / \mathrm{g} \mathrm{DW})$ and HP/17 FLM, $118.38 \pm 0.95 \mathrm{mg}$ CE/g DW) collected in 2014 and 2017 respectively. On the other hand, the lowest amount of total flavonoids similar as with total phenols was determined in one sample of leaf, HP/16FoL-T (61.64 $\pm 0.11 \mathrm{mg} \mathrm{CE} / \mathrm{g} \mathrm{DW})$ harvested in Tetovo, from 2016. Leaf samples from Debar and Mavrovo also showed low amounts of total flavonoids in each harvest year.

\section{Total hypericin}

Total hypericin was also determined in whole herb, in separated leaves and flowers (Table 4). The content of total hypericin ranged from $0.03-0.17 \mathrm{mg} / \mathrm{g} \mathrm{DW}, 0.04-0.29$ $\mathrm{mg} / \mathrm{g}$ DW and $0.07-0.60 \mathrm{mg} / \mathrm{g}$ DW in leaf, herb and flower, respectively.

The highest amount of total hypericin $(0.60 \pm 0.03$ $\mathrm{mg} / \mathrm{g} \mathrm{DW})$ was determined in the sample from flower (HP/15 FL-D) collected in Debar in 2015, followed by one sample of flower from Tetovo (HP/17 FL-T, $0.45 \pm 0.02 \mathrm{mg} / \mathrm{g} \mathrm{DW}$ ) harvested in 2017 and another flower sample from Debar (HP/16 FL-T, $0.45 \pm 0.02 \mathrm{mg} / \mathrm{g}$ DW) collected in 2016. On the other hand, the lowest amount of total hypericin similar as with total phenols and total flavonoids were determined in leaf samples from all three locations of harvest (Tetovo, Debar and Mavrovo). Sample, HP/14 FoL-D collected in Debar, from 2014 had lowest amount of total hypericin $(0.03 \pm 0.01 \mathrm{mg} / \mathrm{g} \mathrm{DW})$.

Table 3. The content of flavonoids in herb, flower and leaf of Hypericum perforatum (mg CE/g DW)

\begin{tabular}{|c|c|c|c|c|c|c|c|c|c|}
\hline \multirow[t]{2}{*}{ Year } & \multicolumn{3}{|c|}{ Tetovo } & \multicolumn{3}{|c|}{ Debar } & \multicolumn{3}{|c|}{ Mavrovo } \\
\hline & herb & flower & leaf & herb & flower & leaf & herb & flower & leaf \\
\hline 2017 & $109.33 \pm 0.83$ & $116.42 \pm 1.04$ & $103.61 \pm 0.45$ & $102.55 \pm 0.27$ & $108.65 \pm 0.34$ & $72.79 \pm 0.89$ & $112.68 \pm 0.29$ & $118.38 \pm 0.95$ & $98.31 \pm 0.34$ \\
\hline 2016 & $73.04 \pm 0.54$ & $110.62 \pm 0.43$ & $61.64 \pm 0.11$ & $117.57 \pm 0.26$ & $125.35 \pm 0.52$ & $102.32 \pm 0.90$ & $89.81 \pm 0.81$ & $116.78 \pm 0.16$ & $86.34 \pm 0.82$ \\
\hline 2015 & $85.72 \pm 0.99$ & $109.12 \pm 0.88$ & $71.12 \pm 0.72$ & $104.75 \pm 0.81$ & $114.38 \pm 0.13$ & $81.58 \pm 0.22$ & $108.84 \pm 0.04$ & $117.53 \pm 0.43$ & $101.01 \pm 0.69$ \\
\hline 2014 & $108.72 \pm 0.31$ & $112.74 \pm 0.65$ & $106.86 \pm 0.21$ & $94.33 \pm 0.30$ & $111.81 \pm 0.43$ & $69.66 \pm 0.47$ & $115.77 \pm 0.40$ & $119.50 \pm 0.67$ & $93.11 \pm 0.13$ \\
\hline
\end{tabular}

$(\mathrm{n}=3), \mathrm{DW}-$ dry weight 
Table 4. The content of hypericin in herb, flower and leaf of Hypericum perforatum (mg/g DW)

\begin{tabular}{|c|c|c|c|c|c|c|c|c|c|}
\hline \multirow[t]{2}{*}{ Year } & \multicolumn{3}{|c|}{$\overline{\text { Tetovo }}$} & \multicolumn{3}{|c|}{ Debar } & \multicolumn{3}{|c|}{ Mavrovo } \\
\hline & herb & flower & leaf & herb & flower & leaf & herb & flower & leaf \\
\hline 2017 & $0.22 \pm 0.03$ & $0.45 \pm 0.02$ & $0.14 \pm 0.02$ & $0.13 \pm 0.02$ & $0.20 \pm 0.02$ & $0.09 \pm 0.02$ & $0.17 \pm 0.01$ & $0.24 \pm 0.01$ & $0.10 \pm 0.03$ \\
\hline 2016 & $0.16 \pm 0.02$ & $0.23 \pm 0.02$ & $0.12 \pm 0.01$ & $0.17 \pm 0.00$ & $0.44 \pm 0.02$ & $0.16 \pm 0.02$ & $0.12 \pm 0.05$ & $0.16 \pm 0.03$ & $0.07 \pm 0.02$ \\
\hline 2015 & $0.11 \pm 0.01$ & $0.30 \pm 0.04$ & $0.08 \pm 0.03$ & $0.29 \pm 0.02$ & $0.60 \pm 0.03$ & $0.17 \pm 0.01$ & $0.06 \pm 0.01$ & $0.10 \pm 0.02$ & $0.05 \pm 0.01$ \\
\hline 2014 & $0.06 \pm 0.01$ & $0.15 \pm 0.02$ & $0.06 \pm 0.01$ & $0.04 \pm 0.01$ & $0.07 \pm 0.01$ & $0.03 \pm 0.01$ & $0.14 \pm 0.02$ & $0.22 \pm 0.02$ & $0.05 \pm 0.01$ \\
\hline
\end{tabular}

According to the monograph of Hyperici herba in $\mathrm{Ph}$. Eur. the value obtained for total hypericin must not be below $0.08 \%$. Today it is known that the cultivation methods could provide plants with higher production of these metabolites, obtaining $0.1 \%$ of naphtodiantrones or even reaching $1.5 \%$ (Longo, R., Schulz, V. 2002).

\section{Statistical analysis}

Two-factor ANOVA $(p<0.05)$ indicated that seasonal variations do not have any significant influence on the content of total phenols, flavonoids and hypericin in St. John's-wort. However, there was statistically significant difference observed in amount $(\mathrm{mg} / \mathrm{g}$ ) of total phenols, total flavonoids and hypericin in different part of the plant (flower, total herb and leaf) as well as locations of harvest (Debar, Mavrovo and Tetovo). From Fig.1, Box-andWhisker plot, it can be seen that the flowers are characterized by higher amount of total phenols, total flavonoids and hypericin compared to total herb and leaf in all three locations.

Detailed analysis of amount of total phenols in total herb, flower and leaf from three locations (Debar, Mavrovo and Tetovo) was conducted by multiple comparison procedure, LSD ( $p<0.05)$. It indicated that in the harvesting period 2014-2017 significant difference was observed in case of flower compared to leaf from Debar $(94.57 \pm 18.29$ to $68.94 \pm 10.09 \mathrm{mg} / \mathrm{g}$ in average per year) and leaf to total herb $(68.94 \pm 10.09$ to $85.76 \pm 8.58$ $\mathrm{mg} / \mathrm{g}$ in average per year), accordingly. No difference was detected between flower and total herb harvested in Debar. In location of Mavrovo following statistical significance was observed: flower to leaf and total herb (83.49 \pm 7.9 to $40.38 \pm 5.58$ and $63.50 \pm 8.77 \mathrm{mg} / \mathrm{g}$ in average per year, consequently) as well as leaf to total herb. Tetovo location was characterized by significant difference between flower to leaf and total herb $(98.395 \pm 15.74$ to $61.71 \pm 4.97$ and $70.13 \pm 6.36 \mathrm{mg} / \mathrm{g}$ in average per year, accordingly). No difference was observed in case of leaf and total herb in this location.

In the case of total flavonoids, $L S D$ ( $p<0.05)$, pointed that amount in flower from Debar was significantly higher than that in leaf $(115.05 \pm 7.26$ to $81.59 \pm 14.71 \mathrm{mg} / \mathrm{g}$ in average per year) and amount in total herb compared to leaf $(104.8 \pm 9.62$ to $81.59 \pm 14.71 \mathrm{mg} / \mathrm{g}$ in average per year). No significant difference was observed between flower and total herb in Debar location. Results from Mavrovo location pointed that flower had significantly higher amount of total flavonoids compared to leaf $(118.05 \pm 1.17$ to $94.69 \pm 6.46 \mathrm{mg} / \mathrm{g}$ in average per year, accordingly), but no difference was determined between flower and total herb $(106.77 \pm 11.66 \mathrm{mg} / \mathrm{g})$ as well as leaf and total herb. Similar were observation for plant material harvested in Tetovo location where significance was determined in case of flower and leaf (112.22 \pm 3.17 and $85.81 \pm 22.8 \mathrm{mg} / \mathrm{g}$ in average per year), but no difference was indicated between flower and total herb $(94.20 \pm 17.88$ $\mathrm{mg} / \mathrm{g}$ in average per year) as well as leaf and total herb.

$L S D(p<0.05)$ showed that hypericin amount was significantly higher in flower compared to leaf and total herb in Debar location $(0.328 \pm 0.24$ to $0.113 \pm 0.07$ and $0.158 \pm 0.10 \mathrm{mg} / \mathrm{g}$ in average per year, consequently), but no difference was determined between flower and total herb. In Mavrovo location no significant difference was determined when amount of hypericin in flower, total herb and leaf was compared $(0.18 \pm 0.06,0.123 \pm 0.05$ and $0.068 \pm 0.02 \mathrm{mg} / \mathrm{g}$ in average per year, accordingly). Flower harvested in Tetovo location was characterized by significantly higher amount of hypericin compared to leaf $(0.283 \pm 0.13$ to $0.10 \pm 0.04 \mathrm{mg} / \mathrm{g}$ in average per year). However, no difference was determined between amount in flower and total herb $(0.138 \pm 0.07)$ as well as total herb and leaf.

According to literature data total phenols and flavonoids were found in amounts of $17.6 \mathrm{mg} / \mathrm{g}$ dry acetone extract, for phenols and $16.85 \mathrm{mg} / \mathrm{g}$ dry acetone extract, for flavonoids (Maskovic et al., 2011). The quantity of total flavonoids was ranged from 0.1 to $1.6 \%$ in different species of Hypericum, with $1.5 \%$ in $H$. perforatum (Pilepic et al., 2013). The content of total phenolic acids in the investigated species of Hypericum was found to be between 1.1-10.4\% and the highest quantity $(10.4 \%$ ) were found in $H$. perforatum (Pilepic et al., 2013). The examined taxa of Hypericum contained flavonoids and phenolic acids in different quantities, although the differences between species and years of harvest were not found to be significant (Pilepic et al., 2013) which also correlate with our findings and results.

The distribution of total phenols and total flavonoids were investigated previously and the highest total phenolic content was found in ethanol extracts of leaf (182.93 mg GAE/g DW), while the highest total flavonoid content was found in ethanol extract of flower (20.50 mg QE/g DW) (Sekeroglu et al., 2017). In our investigation, the highest amount of total phenols and 


\section{Box-and-Whisker Plot}

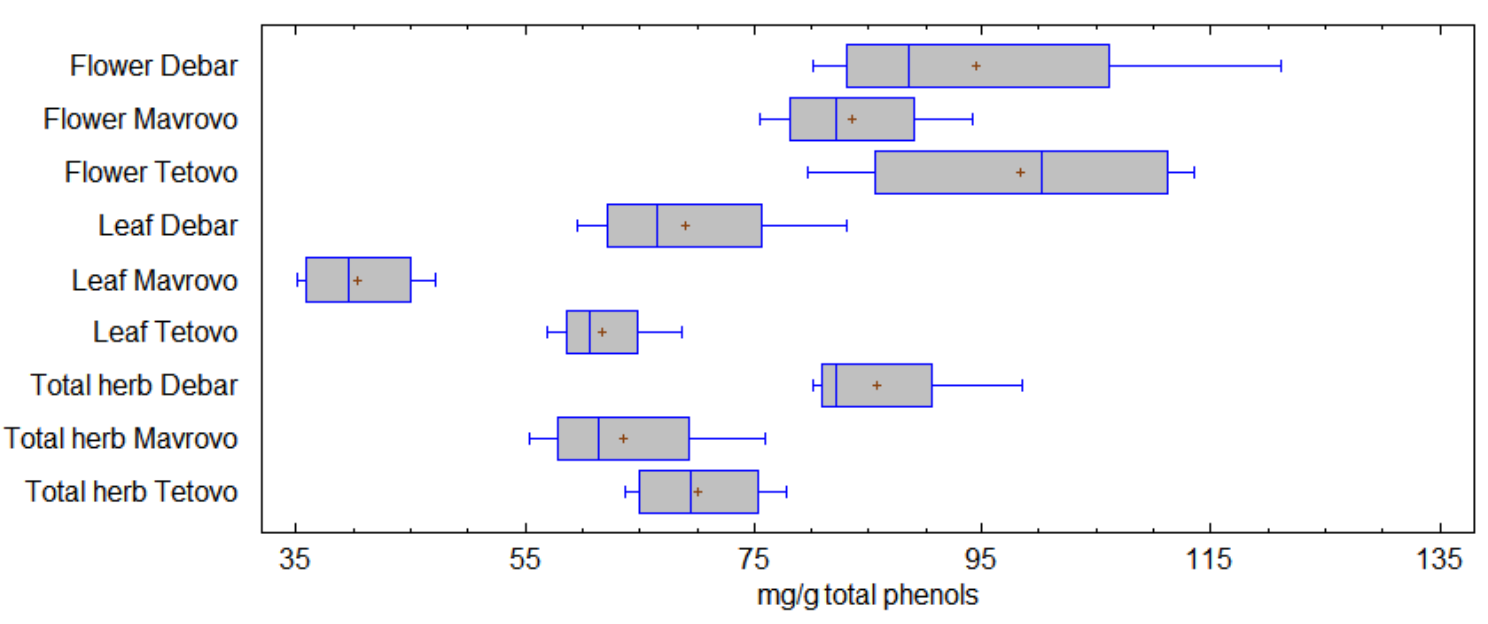

Box-and-Whisker Plot

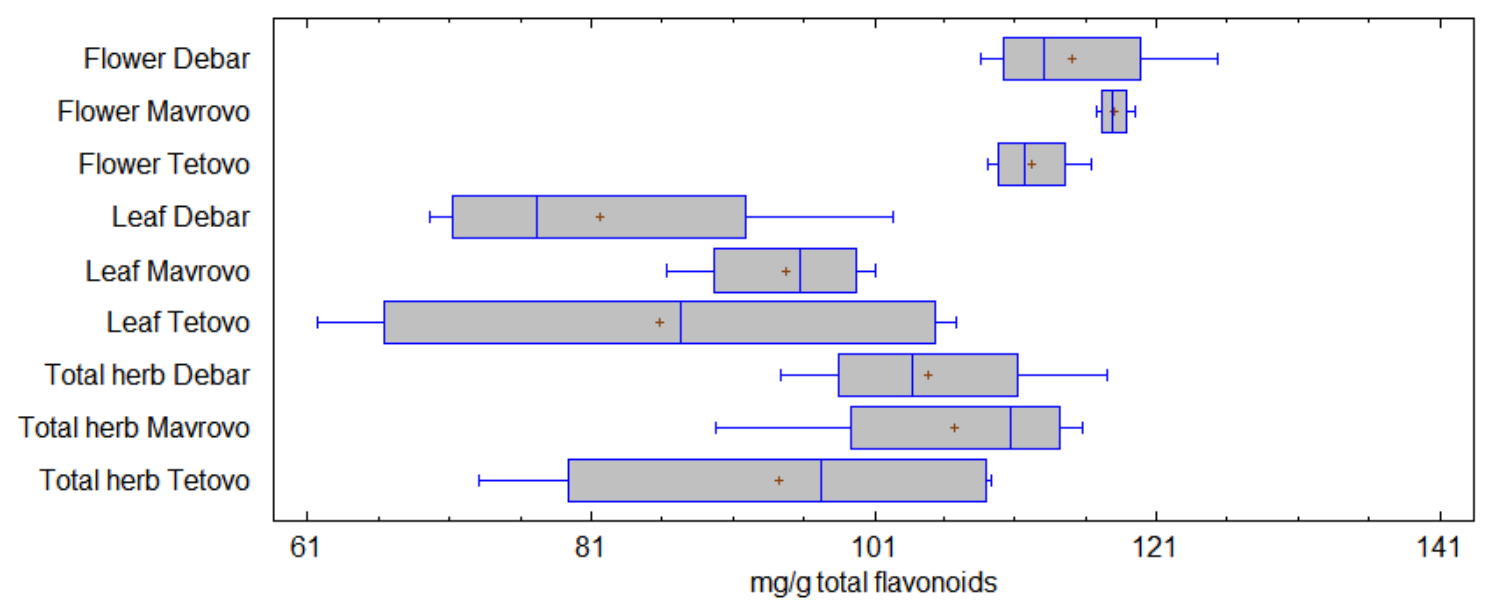

Box-and-Whisker Plot

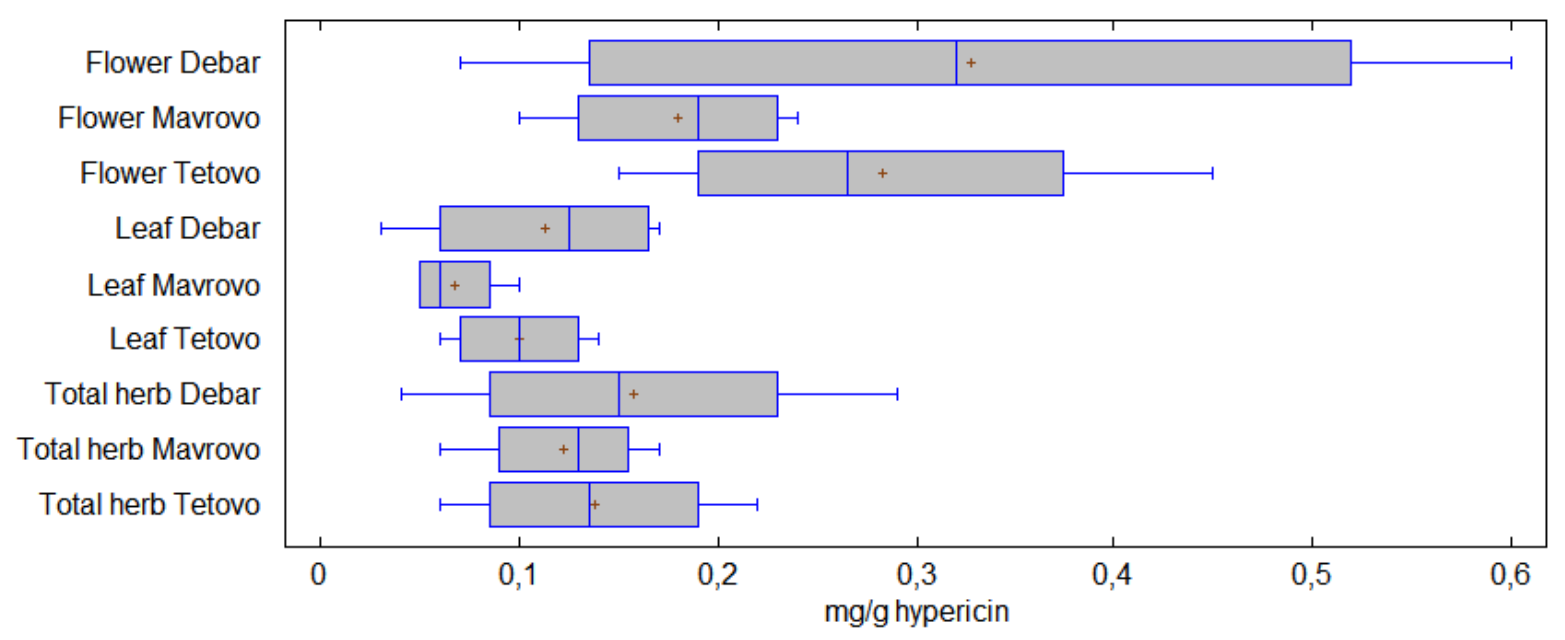

c)

Fig. 1. Box-and-Whisker plot for: a) total phenols, b) flavonoids and c) hypericin in whole herb, flower and leaf of St. John's-wort. 
total flavonoids were determined in sample HP/16 FL-D (sample of flower harvested in Debar in 2016) where they rich the value of $121.19 \mathrm{mg} \mathrm{GAE} / \mathrm{g} \mathrm{DW}$ and $125.35 \mathrm{mg}$ CE/g DW (Table 2 and 3), respectively.

In order to find the optimization of harvest stage to increase bioactive compounds production, the levels of hypericin, flavonoids and polyphenols in Hypericum perforatum as well as antioxidant capacity were previously evaluated by the assays of high performance liquid chromatography (HPLC), $\mathrm{NaNO}_{2}-\mathrm{AlCl}_{3}-\mathrm{NaOH}$ and Folin Ciocalteu as well as 1,1-diphenyl-1-picrylhydrazyl (DPPH) and ferric reducing antioxidant power (FRAP), respectively. It was found that the levels of hypericin, flavonoids and polyphenols in aerial parts decreased during harvest stages, even if bioactive compounds contents in flower reached the highest at blooming stage on a dry weight basis. These findings indicated that the optimization of harvest stage of $H$. perforatum should be at floral budding stage (Sun et al., 2018) which correlate with the results that we obtained for St. John's-wort harvested from three different locations in North Macedonia.

Total hypericins content in stems, leaves, and flowers of some Hypericum species growing in Turkey, was determined by HPLC. The content observed in the study varied greatly depending on species and plant tissues. The lowest levels of hypericin and pseudohypericin were detected in leaves of $H$. hyssopifolium (0.030 and 0.051 $\mathrm{mg} / \mathrm{g}$ DW, respectively) whereas flowers of $H$. montbretii produced the highest levels of both hypericin forms (2.52 $\mathrm{mg} / \mathrm{g}$ DW hypericin and $3.58 \mathrm{mg} / \mathrm{g}$ DW pseudohypericin) (Ayan and Cirak, 2008). The results that we have obtained for distribution of hypericin in different plant organs from $H$. perforatum correlate with the findings of Ayan and Cirak, 2008 and with other available literature data (Repcak and Martonfi, 1997), which can be attributed to the specific defence role of the particular compound. This also could be considered as a natural source of hypericin.

\section{Conclusion}

The content of total phenols, flavonoids and hypericin was determined in whole herb, flowers and leaves of Hypericum perforatum L. (Hypericaceae). Samples were collected during 2014-2017, from three different locations in western part of North Macedonia (Tetovo, Debar and Mavrovo). The content of total phenols ranged from 35.15-83.08 mg GAE/g DW, 55.41-98.52 mg GAE/g DW and 75.44-121.19 mg GAE/g DW, in leaf, whole herb and flower, respectively. On the other hand, the amount of total flavonoids was 61.64-106.86 mg CE/g DW, 73.04$117.57 \mathrm{mg} \mathrm{CE} / \mathrm{g}$ DW and $108.65-125.35 \mathrm{mg}$ CE/g DW in leaf, whole herb and flower, respectively. Finally, the hypericin values were: $0.03-0.17 \mathrm{mg} / \mathrm{g}, 0.04-0.29 \mathrm{mg} / \mathrm{g}$, and $0.07-0.60 \mathrm{mg} / \mathrm{g}$, in leaf, whole herb and flower, respectively. The statistical analysis pointed that season of harvesting did not have any significance, opposite to the location which was identified as significant variable that influenced the amount of total phenols and flavonoids, as well as hypericin, in whole herb, flower and leaf.

From the results it can be anticipated that the flower of $H$. perforatum was most abundant with all three groups of secondary metabolites and most likely it should be advised that harvesting of St. John's-wort should be made in a manner which provides larger amounts of flowers as plant material for extraction and other purposes.

\section{References}

Ayan, A.K., Cirak, C., 2008. Hypericin and pseudohypericin contents in some Hypericum species growing in Turkey. Pharm. Biol. 46, 288-291. Available at: https://doi.org/10.1080/13880200701741211.

Bennett, D.A., Phun, L., Polk, J.F., Voglino, S.A., Zlotnik, V., Raffa, R.B., 1998. Neuropharmacology of St. John's Wort (Hypericum). Ann. Pharmacother. 32, 1201-1208. Available at: https://doi.org/10.1345/aph.18026.

Bradley, P., 2006. British Herbal Compendium. Vol. 2. British Herbal Medicin Association.

Butterweck, V., Jurgenliemk, G., Nahrstedt, A., 2000. Flavonoids from Hypericum perforatum show antidepressant activity in the forced swimming test. Planta Med. 66, 3-6. Available at: https://doi.org/10.1055/s-200011119.

Butterweck, V., Nahrstedt, A., Evans, J., 2002. In vitro receptor screening of pure constituents of St John's wort reveals novel interaction with a number of GPCR's. Psychopharmacol. 162, 193-202. Available at: https://doi.org/10.1007/s00213-002-1073-7.

Calapai, G., Crupi, A., Firenzuoli, F., 1999. Effects of Hypericum perforatum on levels of 5-hydroxytryptamine, noradrenaline and dopamine in the cortex, diencephalon and brainstem of the rat. J. Pharm. Pharmacol. 51, 723-728. Available at: https://doi.org/10.1211/0022357991772862.

Chatterje, S.S., Bhattacharya, S., Wonnemann, M., 1998. Hyperforin as a possible antidepressant component of Hypericum extracts. Life Sci. 63, 499-510. Available at: https://doi.org/10.1016/s0024-3205(98)00299-9.

Cirak, C., Ayan, A.K., Kevseroglu, K., Özen T., 2006. Variation of Hypericin in St John's Worth (Hypericum perforatum) from wild populations of Northern Turkey. Acta Bot. Hung. 48(1), 55-64. Available at: https://doi.org/10.1556/ABot.48.2006.1-2.8.

Crockett, S.L., Robson, N.K., 2011. Taxonomy and chemotaxonomy of the genus Hypericum. Med. Aromat. Plant Sci. Biotechnol. 5, 1-13.

Hamilton, H.B., Hinton, D.R., Law, R.E., Gopalakrishna, R., Su, Y.Z., Chen, Z.H., Weiss, M.H., Couldwel, W.T., 1996. Inhibition of cellular growth and induction of apoptosis in pituitary adenoma cell lines by the protein kinase C inhibitor hypericin: potential therapeutic application. J. Neurosurg. 85, 329-334. Available at: https://doi.org/10.3171/jns.1996.85.2.0329.

Hudson, J.B., Lopez-Bazzocchi, I., Towers, G.H., 1991. Antiviral activities of hypericin. Antiviral Res. 15, 101112. Available at: 
https://doi.org/10.1016/0166-3542(91)90028-p.

Kahkonen, P.M., Hopia, A.I., Vuorela, H.J., Rauha, J., Pihlaja, K., Kujala, T.S., Heinonen, M., 1999. Antioxidant activity of plant extracts containing phenolic compounds. J. Agric. Food Chem. 47(10), 3954-3962. Available at: https://doi.org/10.1021/jf9901461.

Kamuhabwa, A.R., Agostinis, P., D’Hallewin, M.A., Kasran, A., Witte, P.A., 2000. Photodynamic activity of hypericin in human urinary bladder carcinoma cells. Anticancer Res. 20, 2579-2584.

Karapandzova, M., Stefkov, G., Cvetkovikj, I., Stanoeva, J.P., Stefova, M., Kulevanova, S., 2015. Flavonoids and other phenolic compounds in needles of Pinus peuce and other Pine Species from the Macedonian flora. Nat. Prod. Commun. 10(6), 987-990. Available at: https://doi.org/10.1177/1934578X1501000647.

Lavie, G., Valentine, F., Levin, B., Mazur, Y., Gallo, G., Lavie, D., Weiner D., Meruelo, D., 1989. Studies of the mechanisms of the antiretroviral agents hypericin and pseudohypericin. Proc. Natl. Acad. Sci. 86, 5963-5967. Available at: https://doi.org/10.1073/pnas.86.15.5963.

Linde, K., Mulrow, C.D., 2003. St John's wort for depression. Cochrane Database Systematic Reviews. 2, CD000448.

Liu, C.D., Kwan, D., Saxton, R.E., McFadden, D.W., 2000. Hypericin and photodynamic therapy decreases human pancreatic cancer in vitro and in vivo. J. Surg. Res. 93, 137-143.

Longo, R., Schulz, V. 2002. Hypericum The Last Science Discovery Monograph. Natural, 74-79.

Luo, L., Sun, Q., Mao, Y.Y., Lu, Y.H., Tan, R.X. 2004. Inhibitory effects of flavonoids from Hypericum perforatum on nitric oxide synthase. Ethnopharmacol. 93(2-3), 221-225. Available at: https://doi.org/10.1016/j.jep.2004.03.042.

Maskovic, P.Z., Mladenovic, J.D., Cvijovic, M.S., AcamovicDjokovic, G., Solujic, S.R., Radojkovic, M.M., 2011. Phenolic content, antioxidant and antifungal activities of acetonic, ethanolic and petroleum ether extracts of Hypericum perforatum L. Hem. Ind. 65(2), 159-164. Available at: https://doi.org/10.2298/HEMIND100819004M

Meruelo, D., Lavie, G., Lavie, D., 1988. Therapeutic agents with dramatic antiretroviral activity and little toxicity at effective doses: aromatic polycyclic diones hypericin and pseudohypericin. Proc. Natl. Acad. Sci. 85, 5230-5234. Available at: https://doi.org/10.1073/pnas.85.14.5230.

Morales, M.A., Lozoya, X., 1994. Calcium-antagonist effects of quercetin on aortic smooth muscle. Planta Med. 60, 313317. Available at: https://doi.org/10.1055/s-2006-959491.

Müller, W.E., 2005. St. John's wort and its active principles in depression and anxiety, Birkhäuser Verlag, Basel, Switzerland.

Muller, W.E., Singer, A., Wonnemann, M., 2001. Hyperforin antidepressant activity by a novel mechanism of action. Pharmacopsychiatry 34(1), S98-S102. Available at: https://doi.org/10.1055/s-2001-15512.

Nahrstedt, A., Butterweck, V., 1997. Biologically active and other chemical constituents of the herb of Hypericum perforatum L. Pharmacopsychiatry 30, 129-134. Available at: https://doi.org/10.1055/s-2007-979533.

Ph. Eur. European Pharmacopoeia 9th Edition. 2016. Council of Europe.

Pilepic, K. H., Males, Z., Crkvenic, M., 2013. Quantitative analysis of total flavonoids and total phenolic acids in thirty Hypericum Taxa. Nat. Prod. Commun. 8(3), 347349. Available at: https://doi.org/10.1177/1934578X1300800319.

Repcak, M., Martonfi, P., 1997. The localization of secondary substances in Hypericum perforatum flower. Biologia Bratislava, 52, 91-94.

Saddiqe, Z., Naeem, I., Maimoona, A., 2010. A review of the antibacterial activity of Hypericum perforatum L. J. Ethnopharmacol. 131, 511-521. Available at: https://doi.org/10.1016/j.jep.2010.07.034.

Sekeroglu, N., Urlu, E., Kulak, M., Gezici, S., Dang, R., 2017. Variation in total polyphenolic contents, DNA protective potential and antioxidant capacity from aqueous and ethanol extracts in different plant parts of Hypericum perforatum L. Indian J. Pharm. Educ. Res. 51(2S), 1-7. Available at: https://doi.org/10.5530/ijper.51.2s.43.

Singer, A., Wonnemann, M., Muller, W., 1999. Hyperforin, a major antidepressant constituent of St John's wort, inhibits serotonin uptake by elevating free intracellular $\mathrm{Na}+$ Pharmacol. Exp. Ther. 290, 1363-1368.

Singleton, V.L., Rossi, J.A., 1965. Colorimetry of total phenolics with phosphomolybdic-phosphotungstic acid reagents. Am. J. Enol. Viticult. 16, 144-153.

Sun, P., Kang, T., Xing, H., Zhang, Z., Yang, D., Zhang, J., Pare, P.W., Li, M., 2018. Phytochemical changes in aerial parts of Hypericum perforatum at different harvest stages. Rec. Nat. Prod. 13, 1-9. Available at: http://doi.org/10.25135/rnp.77.18.04.267.

Talari, S., Rudroju, S., Penchala, S., Nanna, R.S., 2012. Quantification of total phenolic and total flavonoids contents in extracts of Oroxylum indicum L. Kurz. Asian J. Pharm. Clin. Res. 5(4), 177-179.

Thiede, H.M., Walper, A., 1994. Inhibition of MAO and COMT by Hypericum extracts and hypericin. J. Geriatr. Psychiatry. Neurol. 7(1), S54-S56. Available at: http://doi.org/10.1177/089198879400700114.

Toker, Z., 2009. Variation of total hypericin, phenolic and flavonoid compounds in Hypericum triquetrifolium during its phenological cycle. Pharm. Biol. 47, 285-288. Available at: https://doi.org/10.1080/13880200802578983.

Weber, N.D., Murray, B.K., North, J.A., Wood, S.G., 1994. The antiviral agent hypericin has in vitro activity against HSV1 through non-specific association with viral and cellular membranes. Antivir. Chem. Chemother. 5, 83-90. Available at: https://doi.org/10.1177/095632029400500204.

Wonnemann, M., Singer, A., Siebert, B., 2001. Evaluation of synaptosomal uptake inhibition of most relevant constituents of St John's wort. Pharmacopsychiatry 41(1), S148-S51. Available at: https://doi.org/10.1055/s-200115465.

Wood, S., Huffman, J., Weber, N., Andersen, D., North, J., Murray, B., Sidwell, R., Hughes, B., 1990. Antiviral activity of naturally occurring anthraquinones and anthraquinone derivatives. Planta Med. 56, 651-652. Available at: https://doi.org/10.1007/bf01923366.

Zou, Y., Lu, Y., Wei, D., 2004. Antioxidant activity of a flavonoid rich extract of Hypericum perforatum L. in vitro. J. Agr. Food Chem. 52(16), 5032-5039. Available at: https://doi.org/10.1021/jf049571r. 


\title{
Дистрибуција на вкупни феноли, флавоноиди и хиперицин во различни растителни органи на диворастечки кантарион (Hypericum perforatum L., Нуреricaceae) од Северна Македонија
}

\author{
Аријета Шабани ${ }^{1}$, Марија Карапанџова ${ }^{1}$, Ивана Цветковиќ Каранфилова ${ }^{2}$, \\ Ѓ оше Стефков ${ }^{1}$, Маја Симоноска Црцаревска ${ }^{3}$, Светлана Кулеванова $^{1}$ \\ ${ }^{1}$ Институт за фармакогозија, Фармацевтски факултет, \\ Универзитет „Св. Кирил и Методиј”, ул. Мајка Тереза 47, 1000 Скопје, \\ Република Северна Македонија \\ ${ }^{2}$ Центар за природни производи, Фармацевтски факултет, \\ Универзитет „Св. Кирил и Методиј”, ул. Мајка Тереза 47, 1000 Скопје, \\ Република Северна Македонија \\ ${ }^{3}$ Институт за фармацевтска технологија, Фармацевтски факултет, Универзитет \\ „Св. Кирил и Методиј”, ул. Мајка Тереза 47, 1000 Скопје, \\ Република Северна Македонија
}

Клучни зборови: Hypericum perforatum, растителни органи, вкупни феноли, флавоноиди, хиперицин, статистичка анализа

Hypericum perforatum L. (Нуреricaceae) содржи секундарни метаболити кои покажуваат значајни фармаколошки активности. Затоа, содржината на вкупните феноли, флавоноиди и хиперицин од херба, од цветовите и од листовите од кантарион собрани во текот на четири последователни сезони (2014-2017) од три различни локации во западниот дел на Северна Македонија (Тетово, Дебар и Маврово) беа испитани со три различни спектрофотометриски методи (со Folin-Ciocalteu реагенс, со $\mathrm{NaNO}_{2}-\mathrm{AlCl}_{3}-\mathrm{NaOH}$ и со мешавина од вода/тетрахидрофуран). Содржината на вкупните феноли од различни растителни органи (листови, херба и цветови) изнесува 35,15-83,08 mg GAE/g, 55,41-98,52 mg GAE/g и 75,44-121,19 mg GAE/g, соодветно. Потоа, вкупната содржина на флавоноиди беше: 61,64-106,86 mg CE/g, 73,04-117,57 mg CE/g и 108,65-125,35 mg CE/g во листови, херба и цветови, соодветно, додека количините на хиперицин беа: 0,03-0,17 mg/g, 0,04-0,29 mg/g и 0,07$0,60 \mathrm{mg} / \mathrm{g}$ во листови, херба и цветови, соодветно. Значајни разлики беа забележани во количините на вкупните феноли, флавоноиди и хиперицин помеѓу локацијата на бербата, додека сезоните за собирање се покажаа како не значајни.

Дополнително, може да се види дека цветовите се карактеризираат со поголеми количини на вкупни феноли, вкупни флавоноиди и хиперицин во однос на хербата и листовите на сите три локации, затоа бербата на кантарион треба да се направи на начин за добивање поголема количини на цветови како материјал за собирање што може да ги зголеми биоактивните соединенија во собраната херба. 
